\title{
Analysis of Rat Vestibular Hair Cell Development and Regeneration Using Calretinin as an Early Marker
}

\author{
J. Lisa Zheng and Wei-Qiang Gao \\ Department of Neuroscience, Genentech, Inc., South San Francisco, California 94080
}

Despite increased interest in inner ear hair cell regeneration, it is still unclear what exact mechanisms underlie hair cell regeneration in mammals because of our limited understanding of hair cell development and the lack of specific hair cell markers. In this report, we studied hair cell development using immunohistochemistry on sections prepared from embryonic day (E) 13 to postnatal day 7 rat inner ear tissues. Of many epithelial, neuronal, and glial markers, we found that calcium-binding protein antibodies recognizing calretinin, calmodulin, or parvalbumin labeled immature hair cells in rat vestibular end organs. In particular, calretinin antiserum labeled the initial differentiating hair cells at E15, a stage immediately after the terminal mitosis of hair cell progenitors. The selective immunoreactivity of postmitotic presumptive hair cells, but not supporting cells or peripheral epithelial cells, was confirmed in utricular epithelial sheet cultures. Double labeling with calretinin and bromodeoxyuridine antibodies in long-term cultures showed that only a few mitotic utricular supporting cells became calretinin positive. Thus, although proliferation-mediated regeneration of new hair cells might directly contribute to hair cell regeneration in rat utricles after injury, it is very limited. In addition, double labeling with calretinin and terminal deoxynucleotidyl transferasemediated dUTP nick end labeling (TUNEL) revealed that differentiated hair cells underwent apoptosis during normal development at late embryonic and early postnatal stages in vivo and in vitro. Therefore, these experiments lay the groundwork for the time course of differentiation, regeneration, and apoptosis of mammalian vestibular hair cells. This work also suggests that calcium-binding proteins are useful markers for studies on inner ear hair cell differentiation and regeneration.

Key words: hair cells; supporting cells; differentiation; regeneration; apoptosis; proliferation; vestibular; utricle; TUNEL; calretinin; calmodulin; parvalbumin
Hair cells are the primary receptors in the end organs of the inner ear cochlear and vestibular systems. They play a crucial role in transduction of sound or motion signals from the periphery to the CNS. During embryogenesis, both the cochlear and vestibular end organs are developed from the placode-derived otocyst. The terminal mitosis of hair cell progenitors in rat vestibular end organs occurs between embryonic day (E) 13 and E19 (Sans and Chat, 1982; also, see work done in mouse by Ruben, 1967). In adult mammals, each of the inner ear structures contains a fixed number of hair cells distributed in a highly organized manner. Hair cell loss caused by loud sound, exposure to ototoxic drugs, or aging is a major cause of hearing and balance impairments.

Recent findings that mammalian vestibular hair cells can regenerate after aminoglycoside insult (Forge et al., 1993; Warchol et al., 1993) have produced new excitement for potential treatment of hearing and balance disorders. These observations are an extension of earlier work in avian and lower vertebrate systems in which new hair cells in the inner ear structures can be reproduced after acoustic or aminoglycoside damage (Cotanche, 1987; Cruz et al., 1987; Corwin and Cotanche, 1988; Ryals and Rubel, 1988; Duckert and Rubel, 1990; Hashino et al., 1992; Baird et al., 1993).

Received June 30, 1997; revised Aug. 11, 1997; accepted Aug. 19, 1997.

We thank Drs. Arnon Rosenthal, Ivar Kljavin, and Nancy O'Rourke for helpful discussions, Ms. Sarah Farivar for assistance in some of the cryostat sections, and Ms. Janet Valverde for assistance in the initial immunocytochemistry. We also thank Dr. Annette Lewis for critical reading of this manuscript and Mr. Wayne Anstine for preparation of the figures.

Correspondence should be addressed to Dr. Wei-Qiang Gao, Department of Neuroscience, MS 72, Genentech, Inc., 460 Point San Bruno Boulevard, South San Francisco, CA 94080.

Copyright (C) 1997 Society for Neuroscience $\quad 0270-6474 / 97 / 178270-13 \$ 05.00 / 0$
Studies using tritiated thymidine autoradiography, bromodeoxyuridine (BrdU) immunocytochemistry, and time-lapsed recording have provided evidence that supporting cell proliferation is involved during hair cell regeneration and supporting cells are likely hair cell progenitors (Corwin and Cotanche, 1988; Girod et al., 1989; Balak et al., 1990; Raphael, 1992; Weisleder and Rubel, 1992; Hashino and Salvi, 1993; Jones and Corwin, 1993, 1996; Warchol et al., 1993; Stone and Cotanche; 1994; Yamane et al., 1995; Warchol and Corwin, 1996). In addition to regeneration of new hair cells through proliferation of supporting cells, recent reports suggest that there may also be a direct conversion of supporting cells into hair cells after acoustic or ototoxic damage (Adler and Raphael, 1996; Baird et al., 1996). In these studies, new stereocilia-bearing hair cells are found in the superficial layer of the inner ear epithelium in the presence of a mitotic inhibitor, indicating nonproliferation-mediated regeneration.

Because of our limited understanding of hair cell development and the lack of specific hair cell markers, the exact mechanisms underlying hair cell regeneration in mammals are still not known conclusively. Studies of hair cell regeneration have relied on morphological recovery or regeneration of hair cell stereociliary bundles. However, regrowth of the stereociliary bundles used to identify the presence of hair cells may occur slowly, and damaged hair cells may be able to repair themselves even though their stereocilia are sheared off (Sobkowicz et al., 1992). Identification of specific hair cell markers and understanding of the initial hair cell differentiation events during normal development will facilitate our studies on the mechanisms of hair cell regeneration. Although previous immunohistochemical studies have revealed that some neuronal markers such as antibodies recognizing 
calcium-binding proteins are able to label not only inner ear ganglion neurons but also hair cells (Sans et al., 1986; Dechesne et al., 1993; Pack and Slepecky, 1995; Stone et al., 1996), the expression of the calcium-binding proteins in hair cells has not been linked to hair cell differentiation and survival. In addition, comparison of calcium-binding proteins as hair cell markers with phalloidin has not been made.

In the present study, we have screened for numerous markers known to label selective populations of nervous and epithelial cells. These markers included lectins and molecules specific for neuroepithelial, epithelial, neuronal, and glial cells. Of these, antibodies recognizing calcium-binding proteins including calretinin, calmodulin, and parvalbumin labeled immature hair cells in rat vestibular end organs. In particular, calretinin antiserum labeled the initial, presumptive differentiating hair cells at E15, $2 \mathrm{~d}$ earlier than the appearance of stereociliary bundles as revealed by phalloidin staining. The selective immunoreactivity of postmitotic, early differentiating hair cells, including those that have not acquired stereociliary bundles, was also seen in early postnatal utricular epithelial sheet cultures and utricular sections. Using calretinin as an early hair cell marker, we performed experiments in utricular epithelial sheet cultures to study the cellular mechanisms of hair cell regeneration. We obtained evidence that a few mitotic utricular supporting cells in the cultures have the capacity to differentiate into calretinin-positive cells, presumably new hair cells, although the frequency was very low. In addition to hair cell regeneration, hair cell survival is also critical for maintaining normal hearing and balance functions. We therefore performed cell counts of calretinin-positive, presumptive utricular hair cells at different developmental time points and determined whether apoptosis occurs during normal vestibular hair cell development. Using double labeling with calretinin and terminal deoxynucleotidyl transferase-mediated dUTP nick end labeling (TUNEL), we observed that differentiated vestibular hair cells underwent apoptosis in vivo and in vitro. Taken together, these results advance our understanding of the development and regeneration of mammalian vestibular hair cells.

\section{MATERIALS AND METHODS}

Cryostat sections. Inner ear tissues dissected from E13 through postnatal day (P) 7 Wistar rats were immediately fixed in $4 \%$ paraformaldehyde in $0.1 \mathrm{M}$ phosphate buffer, $\mathrm{pH} 7.4$, for $1-2 \mathrm{hr}$. The preparations were rinsed in PBS, cryoprotected in a $30 \%$ sucrose solution, and embedded in OCT (Miles, Elkhart, IN). Twenty micrometer sections were cut, collected on microscopic slides, and stored at $-20^{\circ} \mathrm{C}$ for immunohistochemistry.

Immunocytochemical staining. Cryostat sections were blocked with $10 \%$ normal goat serum (NGS) in PBS containing $0.1 \%$ Triton X-100 for $20 \mathrm{~min}$ and then incubated with various primary antibodies diluted in PBS containing $3 \%$ NGS and $0.1 \%$ Triton X-100 overnight at $4^{\circ} \mathrm{C}$. The antibodies used recognized a tight junction protein (ZO1, 1:200; Zymed, San Francisco, CA), pan-cytokeratin (1:100; Sigma, St. Louis, MO), calretinin (1:200; Chemicon, Temecula, CA), calmodulin (1:100; Sigma), or parvalbumin (1:100; Sigma). FITC or Texas Red-conjugated secondary antibodies (1:200 and 1:70, respectively; Cappel, West Chester, PA) were used to reveal the labeling patterns. To visualize F-actin, the sections were incubated with $0.5 \mu \mathrm{g} / \mathrm{ml}$ phalloidin-FITC conjugated in PBS for $45 \mathrm{~min}$ at room temperature. For lectin molecules, postnatal utricular sections were incubated with 21 different biotinylated lectins (1:1000; Biotinylated lectin kit I, II and III, Vector Labs, Burlingame, CA) overnight at $4^{\circ} \mathrm{C}$, followed by incubation with a streptoavidin-FITC conjugate (1:200; Amersham, Arlington Heights, IL). The lectin molecules were concanavalin A (ConA), soybean agglutinin, wheat germ agglutinin, Dolichos biflorus agglutinin, Ulex europaeus agglutinin I, Ricinus communis agglutinin I, Ricinus communis agglutinin 120, peanut agglutinin, Griffonia (Bandeiraea) simplicifolia lectin I, Pisum sativum agglutinin, Lens culinaris agglutinin, Phaseolus vulgoris erythroagglutinin, Phaseolus vulgoris leucoagglutinin, Sophora japonica agglutinin, wheat germ agglutinin, Griffonia (Bandeiraea) simplicifolia lectin II, Datura stramonium lectin, Erythrina cristagalli lectin, Lycopersicon esculentum (tomato) lectin, Solanum tuberosum (potato) lectin, and Vicia villosa agglutinin. For labeling of cultured cells, the cells were fixed in $4 \%$ paraformaldehyde in $0.1 \mathrm{M}$ phosphate buffer, $\mathrm{pH} 7.4$, for $30 \mathrm{~min}$ and processed for immunostaining as described for the cryostat sections.

For calretinin and BrdU double labeling, cultured cells were treated with $2 \mathrm{~N} \mathrm{HCl}$ for $40 \mathrm{~min}$ at room temperature after fixation and washed in $0.2 \mathrm{M}$ phosphate buffer, $\mathrm{pH} 7.4$, and PBS. The cells were incubated with a mixture of BrdU monoclonal antibody (1:40; Becton Dickinson, Mountain View, CA) and calretinin antiserum (1:200; Chemicon) in PBS containing $0.1 \%$ Triton X-100 and 3\% NGS overnight at $4{ }^{\circ} \mathrm{C}$, followed by incubation with Texas Red-conjugated goat anti-mouse (1:70; Cappel) and FITC-conjugated goat anti-rabbit (1:200; Vector Labs) secondary antibodies (or 1:70 Texas Red-conjugated goat anti-rabbit and 1:200 FITC-conjugated goat anti-mouse secondary antibodies) at room temperature for $45 \mathrm{~min}$. For calretinin and TUNEL double labeling, utricular sections were first processed for calretinin immunohistochemistry (Texas Red-mediated) and then for TUNEL staining (FITC-mediated) for $1 \mathrm{hr}$ at $37^{\circ} \mathrm{C}$ (Boehringer In Situ Cell Death Detection Kit, Boehringer Mannheim, Indianapolis, IN). Negative controls for TUNEL staining omitted the terminal deoxynucleotidyl transferase; positive controls used preincubation of the sections with $0.05 \%$ DNase (Worthington, Freehold, NJ). Labeled preparations were finally washed in PBS, mounted in Fluoromount-G (Southern Biotechnology, Birmingham, AL), and viewed using a Zeiss Axiophot epifluorescent microscope with $20 \times$ and $40 \times$ lens. Pictures were taken with color Kodak 320 ASA reversal slide films.

After calretinin immunohistochemistry or calretinin/TUNEL double labeling on serial cryostat sections of the utricular tissue prepared from E13-P7 rats, the total number of calretinin-positive cells or calretinin/ TUNEL double-labeled cells was counted from the utricular epithelium. Data were collected from five or more rat utricles and are expressed as mean \pm SEM. ANOVA Bonferroni-corrected test was used for statistical analysis.

Utricular epithelial sheet cultures. Utricular epithelial sheets were prepared by incubation of utricles dissected from P3-P4 Wistar rats in 0.5 $\mathrm{mg} / \mathrm{ml}$ thermolysin (Sigma) in calcium- and magnesium-free HBSS $30-40 \mathrm{~min}$ at $37^{\circ} \mathrm{C}$, as reported previously (Corwin et al., 1995; Zheng et al., 1997). Partially dissociated utricular epithelial cell cultures were prepared by additional brief treatment of the utricular sensory epithelial sheets with a mixture of $0.125 \%$ trypsin and $0.125 \%$ collagenase and gentle trituration (Zheng et al., 1997). The epithelial sheets or the partially dissociated epithelial cells were plated on $0.5 \mathrm{mg} / \mathrm{ml}$ poly-Dlysine-coated 16-well LabTek slides (Nunc, Naperville, IL) in serumsupplemented medium (Basal medium Eagle's plus 10\% horse serum, 5\% fetal bovine serum, $9 \mathrm{mg} / \mathrm{ml}$ glucose, $0.3 \mathrm{mg} / \mathrm{ml}$ glutamine, $25 \mathrm{ng} / \mathrm{ml}$ fungizone, and $10 \mathrm{U} / \mathrm{ml}$ penicillin) (modified from Gao et al., 1991). For partially dissociated cultures, BrdU (1:1000; Amersham) was added to the culture at the time of plating. For undissociated epithelial sheet cultures, $3 \mathrm{~mm}$ gentamicin was added to the cultures on the second day for $2 \mathrm{~d}$, and BrdU was introduced at the time that gentamicin was added. The medium (with or without BrdU) was changed every other day, and the cultures were fixed at various timing points from the time that gentamicin was introduced. BrdU and calretinin double immunostaining was processed as described above. BrdU-positive cells were counted from the sensory epithelium, which was judged by the presence of calretininpositive surviving hair cells. Data are expressed as mean \pm SEM.

\section{RESULTS}

\section{Differentiated hair cells express calretinin in early postnatal inner ear sensory epithelium}

Immunohistochemistry performed on $\mathrm{P} 0-\mathrm{P} 4$ rat utricular sections revealed that most of the markers tested either failed to stain the utricular epithelium or gave nonspecific staining. For example, the neuroepithelial marker nestin (Lendahl et al., 1990) and the brain germinal zone marker GD3 (Gao and Hatten, 1994) failed to label the utricular epithelium (data not shown). Of 21 lectin molecules examined (see Materials and Methods), ConA labeled the entire epithelium, with no distinction between hair cells and supporting cells (see Fig. 2C). Peanut agglutinin labeled the hair cell stereociliary bundles starting at E17 but did not stain 

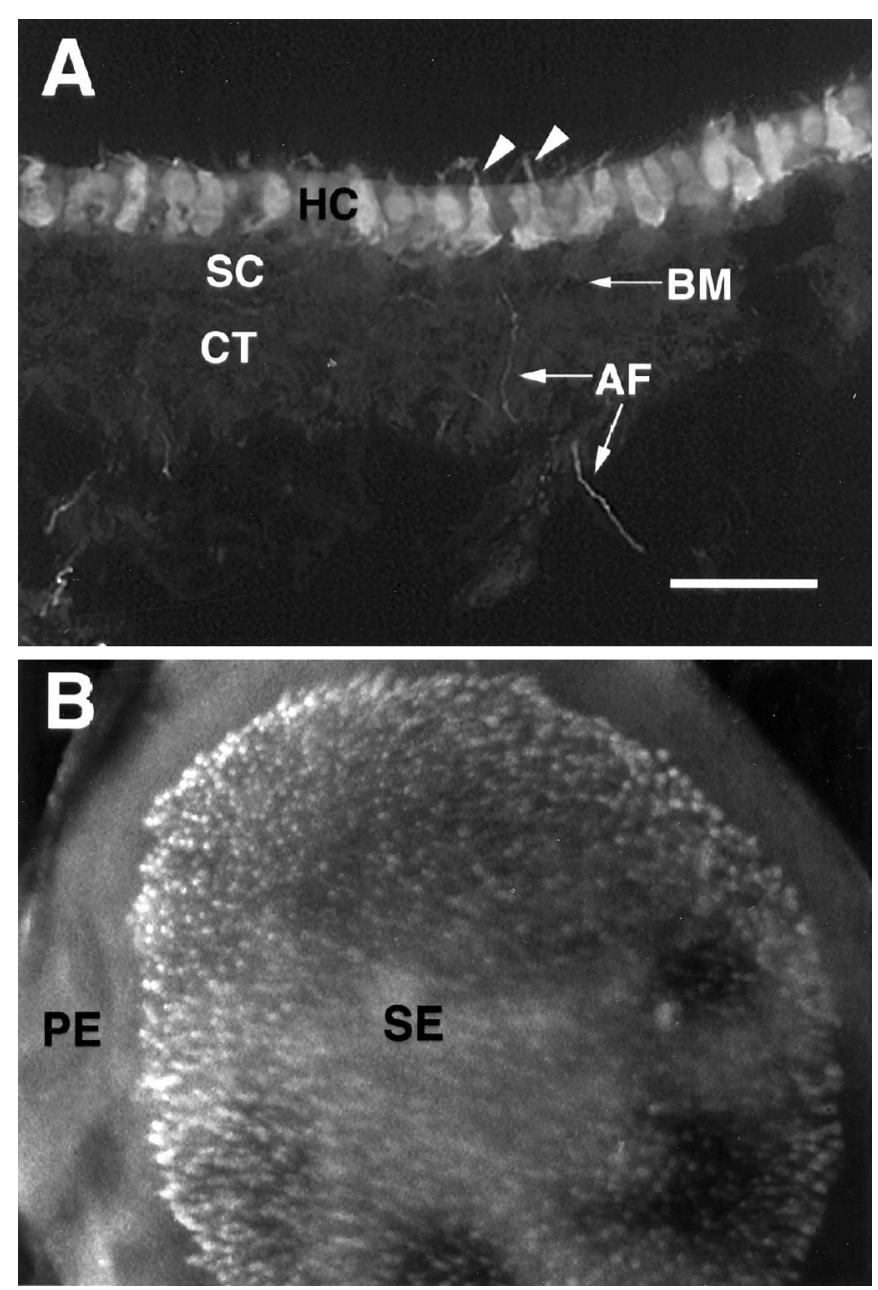

Figure 1. Calretinin immunolabeling of early postnatal utricular section and whole mount. $A$, High magnification micrographs of calretininlabeled hair cells in the lumenal layer of $\mathrm{P} 4$ rat utricular epithelium. $B, \mathrm{P} 4$ utricular whole mount. Arrowheads indicate hair cell stereociliary bundles. $H C$, Hair cells; $B M$, basement membrane; $S C$, supporting cells; $C T$, connective tissue; $A F$, afferent nerve fibers from spiral ganglion neurons; $S E$, sensory epithelium; $P E$, peripheral epithelium. Scale bar (shown in $A): A, 50 \mu \mathrm{m} ; B, 100 \mu \mathrm{m}$.

the hair cell body (data not shown). It also showed nonspecific staining in many mesenchymal tissues. In contrast, an antibody recognizing the calcium-binding protein calretinin specifically labeled hair cells, but not supporting cells, in the utricular epithelium (Fig. 1A). Although some of the afferent nerve fibers innervating the hair cells were also positively labeled, the basement membrane and the underlying connective tissues were not stained by the antibody (Fig. $1 A$ ). The immunoreactivity of the calretinin antibody was also seen in utricular whole-mount preparations (Fig. 1B). Examination of the entire area of the utricular epithelium revealed that only the hair cells located in the central sensory epithelium were labeled, whereas the epithelial cells in the peripheral epithelium were negative (Fig. $1 B$ ). The calretinin antibody labeled entire hair cells, including the stereociliary bundles (Figs. $1 A, 4 B$ ).

\section{Appearance of calretinin coincides with the initial differentiation of hair cells in rat inner ears}

To determine when calretinin is initially expressed during hair cell development, we performed calretinin immunolabeling on cryostat sections of the inner ear tissues from E13, E14, E15, E16, E17, E19, E20, P0, P1, P3, and P4 and compared that with other general epithelial markers (Zheng et al., 1997), including ZO1 (a tight junction protein), cytokeratin, ConA, and phalloidin. ZO1 labeled the tight junction regions between the cells located in the superficial layer of the inner ear epithelium at all stages (E13-P4) (Fig. 2A). Cytokeratin appeared to label the nonsensory roof epithelial cells but not the sensory epithelial cells. The staining began to be seen at E15 and became stronger at E17 (Fig. 2B). ConA staining showed up at E16 and became more intense around the birth, labeling all cells in the epithelium (Fig. 2C). Small phalloidin-stained stereociliary bundles initially appeared at E17 (Fig. 2E) but not at E15 (Fig. 2D) or E16 (data not shown). Stereociliary bundle staining became stronger and more obvious by E19 (Fig. 2F) and thereafter. Unlike the general epithelial markers, which did not show a difference between differentiating hair cells and supporting cells, calretinin staining of differentiating hair cells could be seen as early as E15 (Fig. 3B), $2 \mathrm{~d}$ before the appearance of stereociliary bundles (Fig. 2D,E). At E17, more immature hair cells in the superficial layer were labeled (Figs. 3C, 7B). By E19, hair cells in the three vestibular end organs (saccule, utricle, and crista) were brightly labeled (Fig. $3 D-F$ ), and $\sim 70 \%$ of utricular hair cells were generated by this stage (Fig. $7 B$ ). Because the bulk of terminal mitosis of hair cell progenitor in rats occurs at E14-E18 (Ruben, 1967; Sans and Chat, 1982), the presence of calretinin appears to coincide with the initial differentiation of the inner ear hair cells and occurs before formation of stereociliary bundles.

\section{Calretinin is also a hair cell marker in vitro}

Because cell cultures offer simpler and more accessible systems than the in vivo complicated inner ear bony structures for studies on hair cell development (Van De Water, 1976; Kelley et al., 1993), regeneration (Warchol et al., 1993; Lambert, 1994; Yamashita and Oesterle, 1995; Stone et al., 1996; Zheng et al., 1997), and survival (Zheng and Gao, 1996), it is important to determine whether calretinin can be used as a marker for hair cells in vitro. We immunolabeled utricular epithelial sheets prepared from P3 rats and maintained in culture for $2 \mathrm{~d}$ (Corwin et al., 1995; Zheng et al., 1997). As shown in Figure $4 A$, calretinin antibody selectively labeled immature hair cells in the sensory epithelium region. Double labeling of the utricular epithelial sheets with calretinin antibody and phalloidin indicated that the stereociliary bundles of all hair cells in the central sensory epithelium were double-labeled (Fig. 4B). At the border between the sensory epithelium and peripheral nonsensory epithelium, a few calretinin-positive cells were not double-labeled by phalloidin, or the stereociliary bundles of the calretinin-positive cells were much shorter than those in the central sensory epithelium (Fig. $4 C$ ). The detection of cells that have not acquired stereociliary bundles by the calretinin antibody was also frequently observed in the marginal zone of the sensory epithelium of P3 utricular sections. One of the examples is shown in Figure $4 D$. These observations suggest that the calretinin-positive cells at the border are likely to be hair cells at a younger stage than those in the central region, which is consistent with other reports indicating that hair cells in the central region (striola) are born earlier and acquire taller stereociliary bundles than those in the peripheral region in the mouse or guinea pig utricles (Sans and Chat, 1982; $\mathrm{Gu}$ et al., 1997). Such appositional addition of new hair cells at the edge of sensory epithelium has also been reported in fish and amphibian ears (Corwin, 1981, 1983, 1985). Therefore these 

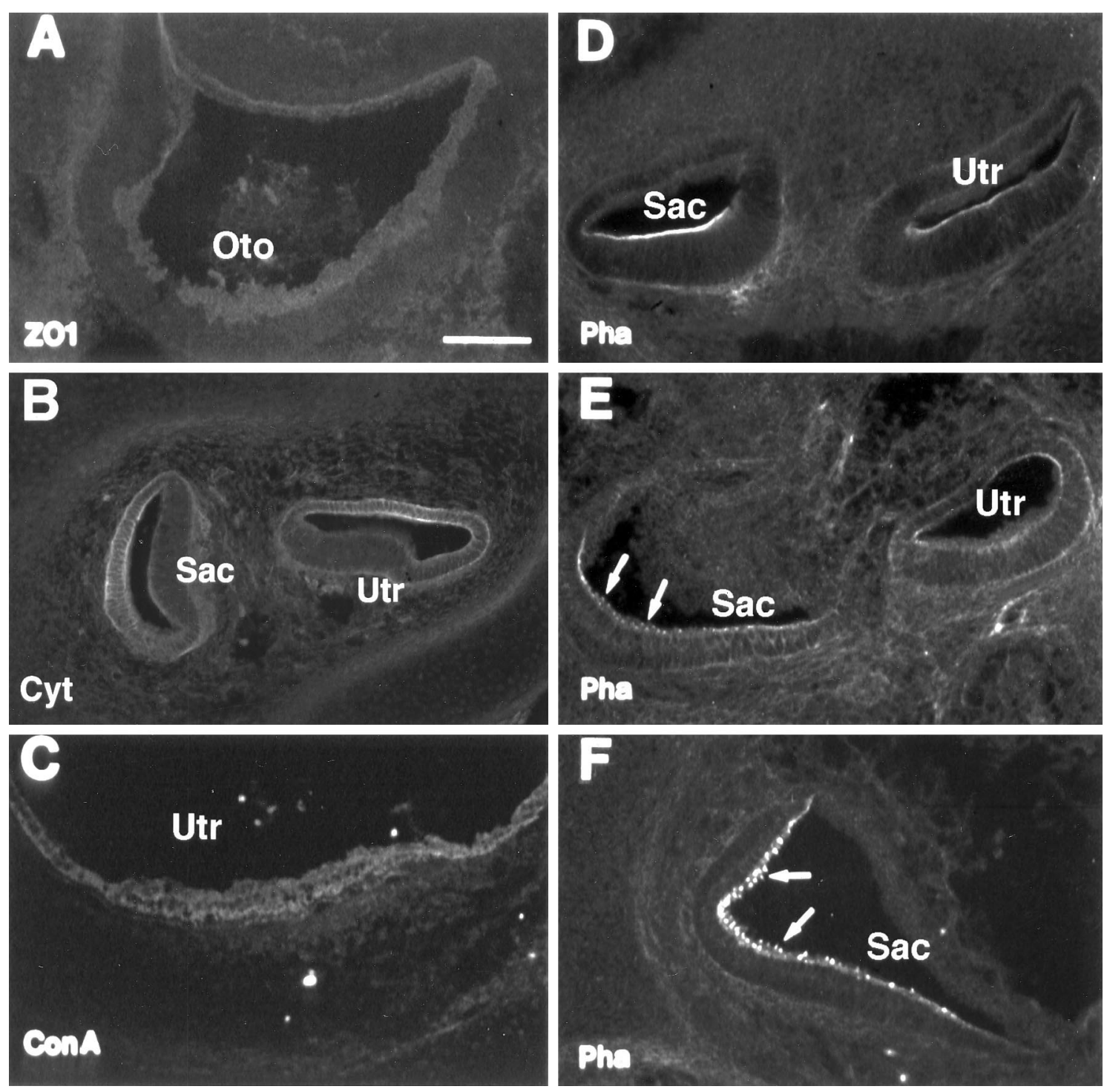

Figure 2. Immunolabeling of developing inner ear tissues with general epithelial markers. $A, \mathrm{ZO} 1$ immunostaining at E13. $B$, Cytokeratin antibody labeling at E17. $C$, ConA labeling at P0. $D-F$, Phalloidin labeling at E15, E17, and E19, respectively. Arrows indicate the appearance of hair cell stereociliary bundles. Oto, Otocyst; Utr, utricle; Sac, saccule. Scale bar (shown in $A$ ): $A, 50 \mu \mathrm{m} ; B-F, 100 \mu \mathrm{m}$.

findings support the notion that calretinin can be used as an early hair cell marker in vitro.

\section{Calretinin is expressed only by postmitotic cell populations}

To determine whether calretinin is present in any mitotic progenitor cells in the utricular epithelium, we added BrdU to partially dissociated utricular sensory epithelial cell cultures (Zheng et al., 1997) followed by double immunocytochemistry with antibodies recognizing calretinin and BrdU. Although calretinin antibody labeled the surviving hair cells, BrdU stained the mitotic supporting cells. The calretinin and BrdU labelings were mutually exclusive in 20 cultures from several separate experiments (data not shown). No double-labeled cells were observed when BrdU was present in the cultures for $2 \mathrm{~d}$ and the cultures were fixed and examined at $2 \mathrm{~d}$ in vitro. The same results were obtained in undissociated, intact utricular epithelial sheet cultures (Table 1). These data suggest that calretinin exclusively labels only the postmitotic differentiating hair cells but not the mitotic progenitors in the utricular epithelium.

\section{A very limited number of mitotic supporting cells have the capacity to give rise to calretinin-positive cells in vitro}

One important issue regarding hair cell regeneration in mammals is whether mitotic supporting cells have the capacity to differentiate into new hair cells after injury. To examine this issue, we introduced BrdU to utricular epithelial sheet cultures that contained primarily supporting cells and hair cells for $2 \mathrm{~d}$, and performed calretinin and BrdU double immunocytochemistry. There was virtually no cell division in cultured intact postnatal utricular sensory epithelium (Table 1) (the minimal cell division seen could be attributable to accidental damage during dissections) (Warchol et al., 1993; Yamashita and Oesterle, 1995). When the cultures were treated with $3 \mathrm{~mm}$ gentamicin for $2 \mathrm{~d}$ and further cultured in the presence of BrdU for an additional 7-11 d, $\sim 23 \%$ of hair cells (calretinin-positive cells: $499.5 \pm 37.7, n=12$ vs $2216.2 \pm 91.2, n=11$ in control cultures) survived gentamicin treatment (Fig. 5) and proliferation of supporting cells was seen (Table 1). Under these culture conditions, a few of the mitotic 

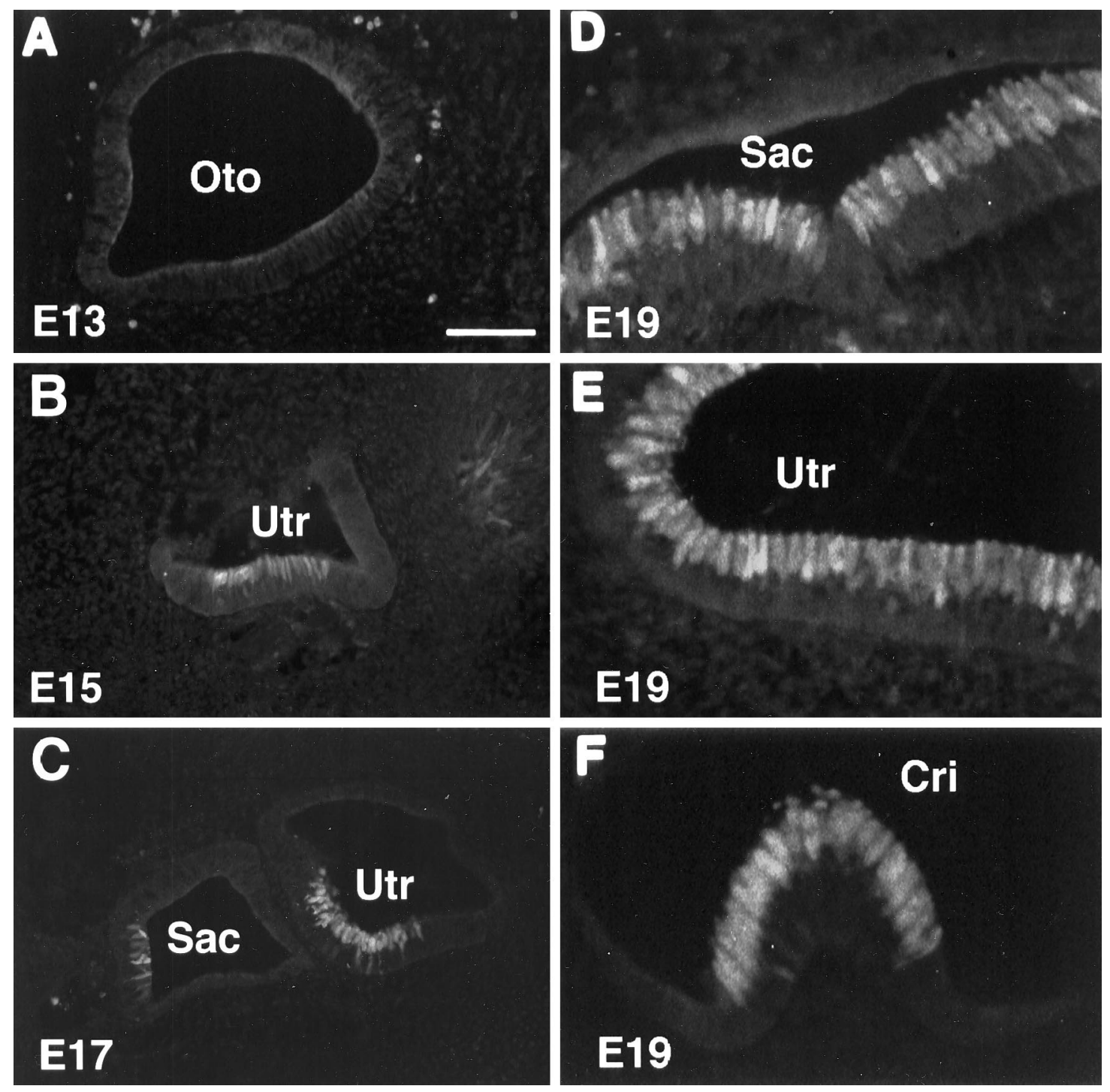

Figure 3. Calretinin immunolabeling of embryonic inner ear tissues. $A, B, C, \mathrm{E} 13$, E15, and E17, respectively. $D, E, F$, The saccule, utricle, and crista at E19, respectively. Note the earliest appearance of calretinin in the lumenal layer of the inner ear epithelium at E15. Oto, Otocyst; Sac, saccule; Utr, utricle; $C r i$, crista. Scale bar (shown in $A$ ): $A-C, 100 \mu \mathrm{m} ; D-F, 50 \mu \mathrm{m}$.

cells were also double-labeled by BrdU and calretinin antibodies (Table 1). Three examples of these cultures are shown in Figure $5 A-C$. Double labeling of the undissociated utricular epithelial sheet cultures treated with $3 \mathrm{~mm}$ gentamicin in the presence of BrdU for a shorter period of time ( 2 hr to $5 \mathrm{~d}$ ) with BrdU and calretinin antibodies failed to reveal any double-labeled cells (Table 1), suggesting that a time longer than $5 \mathrm{~d}$ is required for the generation of presumably new hair cells in these cultures. The failure of detection of any double-labeled cells in short-term cultures ( $2 \mathrm{hr}$ to $5 \mathrm{~d}$ ) also suggests that the double labeling is less likely to be the result of DNA repair of damaged hair cells.

Interestingly, the calretinin and BrdU double-labeled cells were always seen as single cells (Fig. 5). In some cases, a supporting cell (BrdU-positive but calretinin-negative cell) could be seen sitting adjacent to the double-labeled cell (Fig. $5 B$ ), suggesting a possibility that the two cells might be the daughter cells of the same mitotic progenitor. The number of double-labeled cells was very low. Only 27 double-labeled cells were observed from 63 undissociated utricular epithelial sheets maintained for 10-14
DIV (Table 1). It is possible that the continuous presence of BrdU could be toxic, which might affect the survival of newly differentiated hair cells and result in an underestimation of differentiation or regeneration of new hair cells. The calretininpositive cells in epithelial sheet cultures failed to grow stereociliary bundles, as revealed with phalloidin staining (data not shown) (also see Stone et al., 1996), suggesting that growth of stereocilia or further maturation of hair cells might require a more intact microenvironment, such as that of the utricular whole mounts (Forge et al., 1993; Warchol et al., 1993), which contain not only the epithelium but also the basement membrane and underlying connective tissues.

\section{Some differentiated hair cells undergo apoptosis in developing vestibular epithelia in vivo and in vitro}

To determine whether a fraction of the hair cells undergo apoptosis after differentiation during normal development, we performed TUNEL staining with inner ear tissues prepared from E13, E15, E17, E19, P0, P3, and P7 rats. Although no TUNEL 

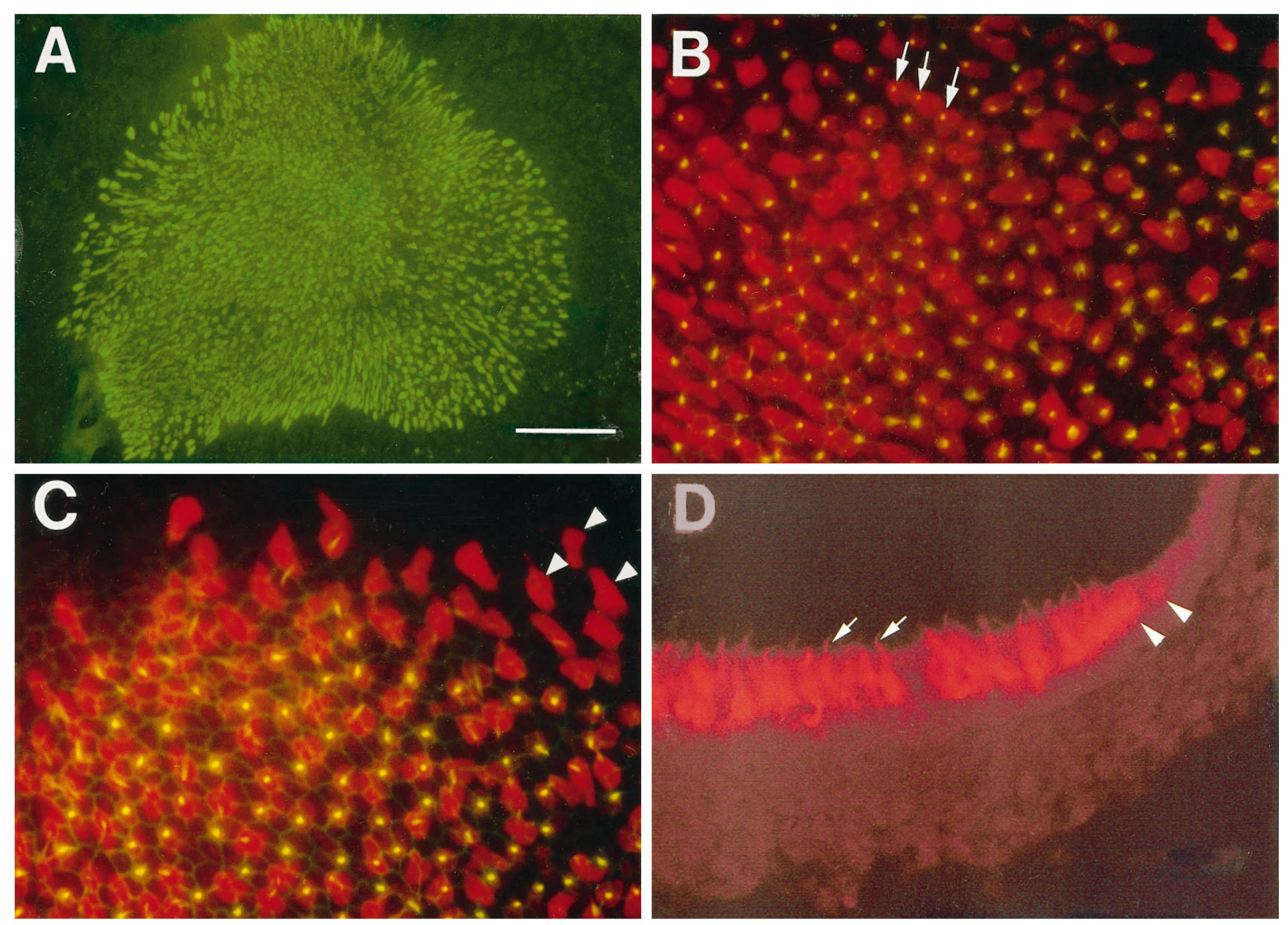

Figure 4. Calretinin antibody and phalloidin labeling in utricular sheets maintained in cultures for 2 d and in P3 utricular sections. $A$, Calretinin antibody labeling (FITC-mediated) of a cultured P3 utricular epithelial sheet. B, C, High magnification of cultured P3 utricular epithelial sheets double-labeled with calretinin antibody (red) and phalloidin (green). The yellow color of the stereocilia (arrows) indicates the overlapping satining. $D$, Calretinin antibody labeling (Texas Red-mediated) of a P3 utricular section showing that two presumptive hair cells (arrowheads) have not acquired stereociliary bundles. Note that a few calretinin-positive cells at the border between sensory epithelium and nonsensory epithelium were not double-labeled by phalloidin (arrowheads) in $C$. Scale bar (shown in $A$ ): $A, 200 \mu \mathrm{m} ; B, C, D, 50 \mu \mathrm{m}$.

Table 1. Summary of BrdU and calretinin double immunocytochemical labeling in the undissociated utricular epithelial sheet cultures either untreated or treated with 3 mm gentamicin

\begin{tabular}{|c|c|c|c|c|c|c|}
\hline & \multirow[b]{2}{*}{ Untreated } & \multicolumn{5}{|l|}{ Treated } \\
\hline & & $2 \mathrm{hr}$ & $2 \mathrm{~d}$ & $5 \mathrm{~d}$ & $7 \mathrm{~d}$ & $11 \mathrm{~d}$ \\
\hline $\begin{array}{l}\text { Number of double-labeled cells } \\
\text { versus number of utricular } \\
\text { sheets }\end{array}$ & $0 / 10$ & $0 / 9$ & $0 / 12$ & $0 / 20$ & $13 / 28$ & $14 / 35$ \\
\hline $\begin{array}{l}\text { Number of BrdU-positive cells } \\
\text { per sensory epithelium }\end{array}$ & $\begin{array}{l}2.1 \pm 0.5 \\
(n=10)\end{array}$ & $\begin{array}{l}0.3 \pm 0.3 \\
(n=9)\end{array}$ & $\begin{array}{l}9.2 \pm 1.0 \\
(n=12)\end{array}$ & $\begin{array}{l}21.5 \pm 2.7 \\
(n=20)\end{array}$ & $\begin{array}{l}35.7 \pm 3.3 \\
(n=28)\end{array}$ & $\begin{array}{l}30.3 \pm 3.4 \\
(n=35)\end{array}$ \\
\hline
\end{tabular}

Utricular epithelial sheets were prepared from P3 rats. For untreated cultures, BrdU was added at the time of plating for 2 d before fixation. For gentamicin-treated cultures, $3 \mathrm{~mm}$ gentamicin was added to the cultures on the second day for $2 \mathrm{~d}$, and BrdU was introduced at the time that gentamicin was added. The medium (with or without BrdU)

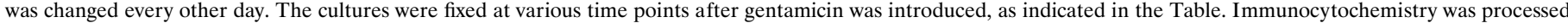

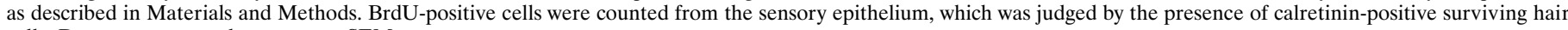
cells. Data are expressed as mean \pm SEM.

labeling was observed in the inner ear epithelium at ages E13E17, positive staining was seen in the tissues from E19 to P7. Pyknotic nuclei (TUNEL staining) were seen in some of the differentiated hair cells (calretinin positive) located in the lumenal layer of the sensory epithelia within each of the vestibular end organs, including saccules (Fig. 6A,B), utricles (Fig. 6C), and cristae (Fig. 6D). Cell counts of calretinin and TUNEL doublelabeled apoptotic hair cells from serial utricular sections are shown in Figure $7 A$. The peak level of apoptosis was seen at P3. By $\mathrm{P7}$ the number of apoptotic hair cells declined greatly. 

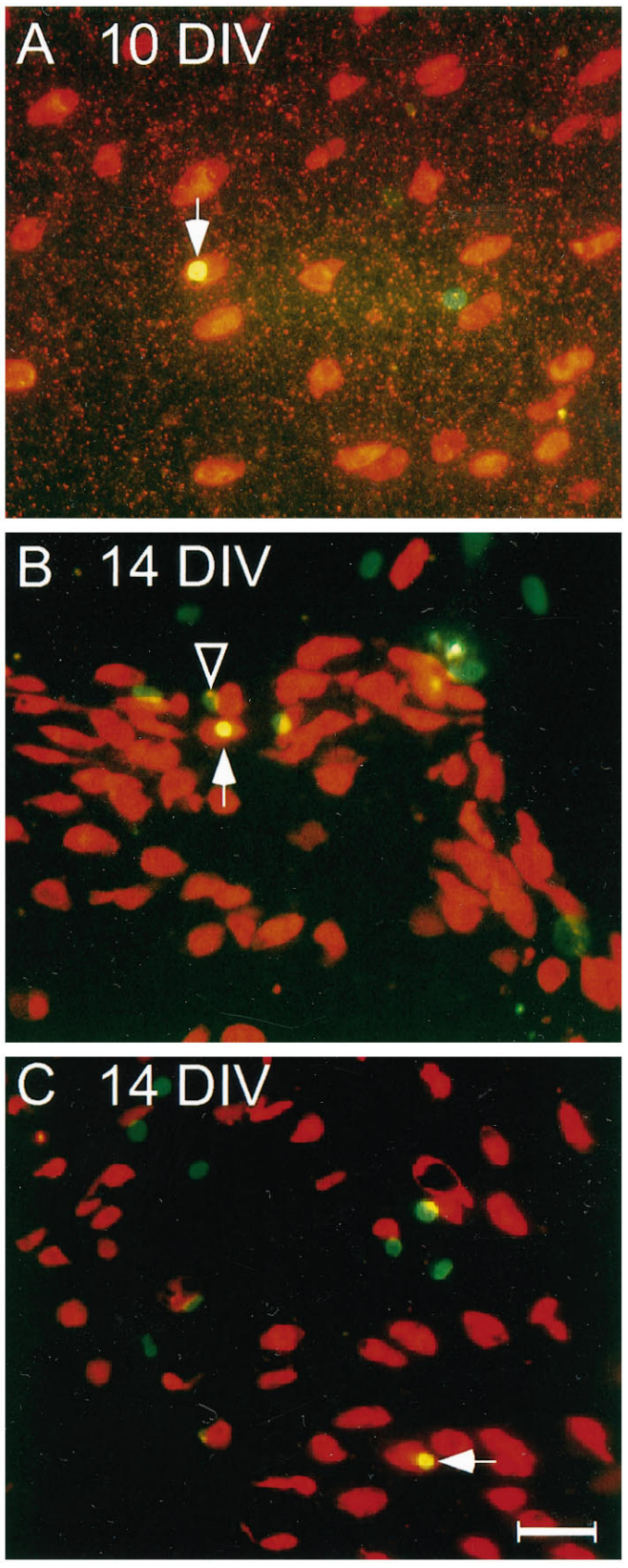

Figure 5. Double calretinin and BrdU immunocytochemistry in three undissociated utricular epithelial sheet cultures maintained 10-14 DIV. The cultures were exposed to $3 \mathrm{~mm}$ gentamicin on the second day for $2 \mathrm{~d}$, and $\mathrm{BrdU}$ was included in the medium after gentamicin was added. Texas Red- and FITC-conjugated secondary antibodies were used to reveal the staining patterns of calretinin and BrdU, respectively. Note that the arrows point to the double-labeled presumptive hair cells, and the arrowhead indicates that a supporting cell (BrdU positive but calretinin negative) is localized close to a presumptive newly generated hair cell, which may arise from the same mitotic precursor cell. Scale bar, $40 \mu \mathrm{m}$.

TUNEL labeling of either the cultured utricular epithelial sheets or partially dissociated pure utricular sensory epithelial cells prepared from P3-P4 rats at 2 DIV also showed apoptotic cell death occurring in calretinin-positive presumptive hair cells with a rate comparable to that of the in vivo situation (Fig. 6E,F). Cell counts in cultured P3 utricular epithelial sheets revealed an average of $\sim 52$ apoptotic cells $(n=11)$ at 2 DIV in the entire sensory epithelial area judged by the presence of calretinin-positive cells.
The TUNEL staining was specific, because no positive labeling was seen when the E13-E17 tissues were examined (not shown) or when the terminal deoxynucleotidyl transferase was omitted. The percentage of TUNEL-positive hair cells was low but reproducible. The relatively low number of apoptotic cells could be attributed to the fact that TUNEL staining picks up apoptotic cells only in a narrow time window.

To determine temporal progression of hair cell differentiation and to provide supporting evidence for hair cell apoptosis, which is expected to lead to a possible reduction in differentiated hair cell numbers in postnatal rats, we counted the total number of calretinin-positive cells within the utricular epithelium at different developmental time points from E13 to P7. As shown in Figure $7 B$, a small number of presumptive hair cells arose as early as E15, and by P0 most hair cells were born. Although there was still an increase from $\mathrm{P} 0$ to $\mathrm{P} 3$, a statistically significant decrease was seen in the hair cell number from P3 to P7 (2209.2 \pm 79.72 , $n=10$ at $\mathrm{P} 3$ vs $1934.3 \pm 88.6, n=10$ at P7; $p<0.01)$. These results suggest that although hair cell apoptosis starts as early as E19, more new hair cells seem to be differentiated than those undergoing apoptosis between P0 and P3. In contrast, more cell death occurred between P3 and P7. These postnatally differentiated hair cells are likely to be added to the marginal zone of the utricular sensory epithelium, as shown in Figure $4 C, D$ (Corwin, 1981, 1983, 1985; Sans and Chat, 1982).

\section{Other calcium-binding proteins such as calmodulin and parvalbumin can also be used as inner ear hair cell markers}

To find out whether other calcium-binding proteins are also present selectively in the immature hair cells, we performed immunocytochemistry with antibodies recognizing calmodulin and parvalbumin in the developing inner ear tissues in vivo and in vitro. Similar to calretinin antibody, calmodulin and parvalbumin antibodies also labeled entire immature hair cells, including stereociliary bundles but not supporting cells, in the inner ear epithelium. Examples of these labelings are shown in Figure 8. However, the appearance of calmodulin or parvalbumin occurred a few days later than calretinin during embryonic development: the earliest labeling with calmodulin and parvalbumin antibodies occurred at E17 and E19, respectively. The labeling intensity of calmodulin and parvalbumin, however, was much weaker than that of calretinin, especially at E17-E19. Nevertheless, the staining intensity by calmodulin and parvalbumin was sufficient to identify hair cells after E19 in vivo (Fig. $8 A, B, D$ ) and in the cultured postnatal utricular epithelial sheets (Fig. $8 C$ ). When double immunocytochemistry was performed in the utricular epithelial sheet cultures prepared from neonatal rats, staining by the antibodies recognizing calmodulin and calretinin overlapped very well (data not shown).

\section{DISCUSSION}

\section{Developmental time course of hair cell differentiation in rat vestibular end organs}

We have studied the developmental time course of rat vestibular hair cell differentiation in vivo from E13 to P7 using immunohistochemistry. The earliest detectable expression of the hair cell marker calretinin occurs at E15, a stage immediately after terminal mitosis of hair cell progenitors (E13-E19 in rats) (Ruben, 1967; Sans and Chat, 1982). The calretinin labeling in the lumenal layer of the inner ear epithelium seems to coincide with the initial differentiation of hair cells. The immunohistochemical character- 

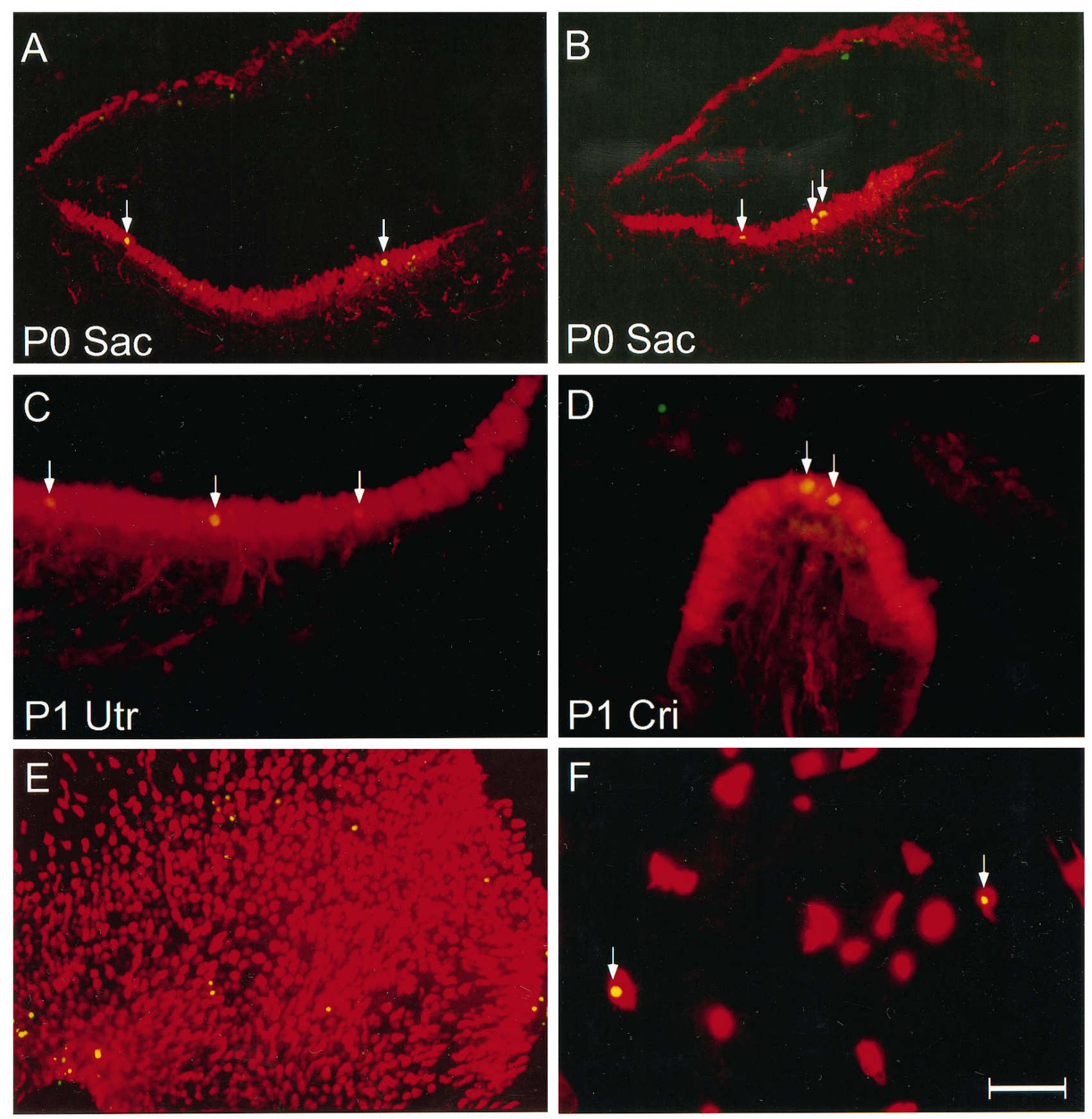

Figure 6. Double labeling of calretinin antibody (red) and TUNEL ( green) in neonatal inner ear sections and in cell cultures. $A, B, \mathrm{P} 0$ saccules; $C$, P1 utricle; $D$, P1 crista; $E, F$, cultured utricular epithelial sheet and partially dissociated utricular epithelial cells prepared from P3 rat at 2 DIV, respectively. Arrows indicate the apoptotic hair cells. Overlapping label appears yellow. Sac, Saccule; Utr, utricle; Cri, crista. Scale bar (shown in F): $A, B, E$, $100 \mu$ m; $C, D, F, 50 \mu \mathrm{m}$.

ization of hair cell differentiation is easier and less ambiguous than the traditional electron microscopy or phalloidin staining. As compared with the developmental timeline proposed by Kelley et al. (1993) for mouse cochlear hair cells, we would make the following modification for the development of hair cells in rat vestibular system (Fig. 9). There seems to be a rapid early differentiation of hair cells or a commitment of hair cell fate immediately after terminal mitosis. The previously proposed prosensory cells (Kelley et al., 1993) perhaps do not exist or last only for a relatively short time in the vestibular end organs. Differentiation seems to occur mainly from E15 to P0. By E17 many of the differentiating hair cells in the central sensory epithelium have acquired short stereociliary bundles. Although the vast majority of the hair cells have been generated by $\mathrm{P} 0$, there still is an addition of a small number of new hair cells from P0 to P3. After E19, other calcium-binding proteins, including calmodulin and parvalbumin, are also expressed by the differentiating hair cells. Between E19 and P7, there is a low level of apoptosis that is very close to the time window proposed by Kelley et al. (1993). There is a central-to-peripheral gradient of onset for each of the developmental steps in the utricular epithelium. Mechanisms such as lateral inhibition (Corwin et al., 1991; Lewis, 1991) may play an 

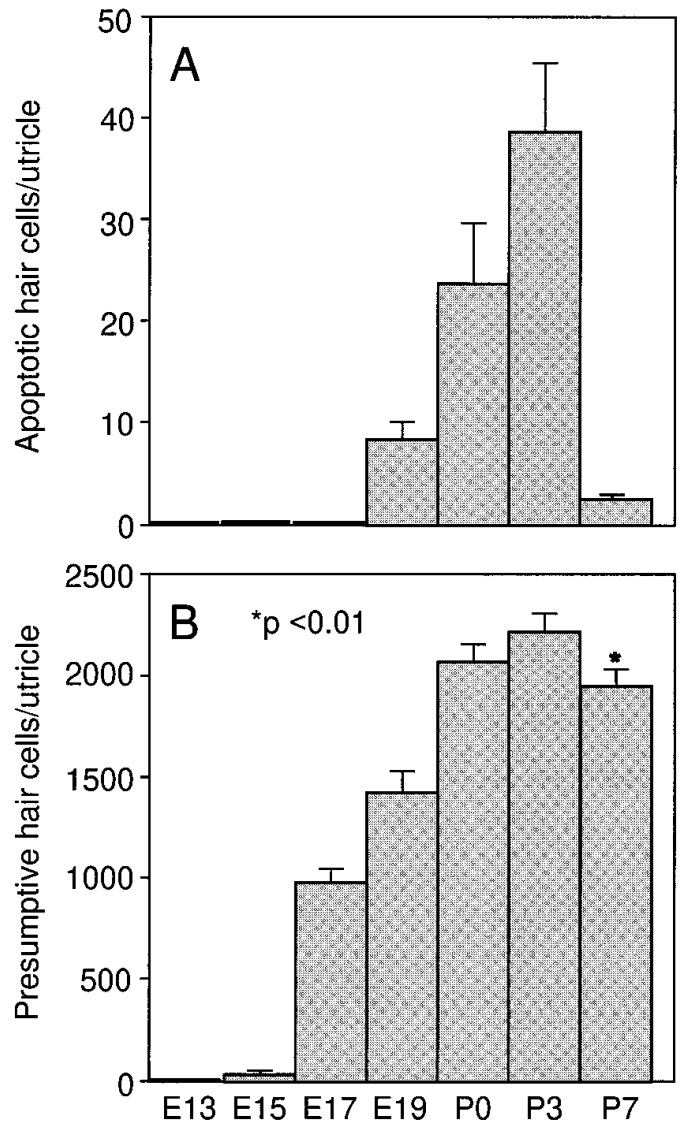

Figure 7. Cell counts of apoptotic hair cells and total presumptive hair cells in the rat utricle at different developmental time points. $A$, Number of calretinin and TUNEL double-labeled cells in the utricular epithelium. $B$, Total number of calretinin-positive presumptive hair cells in the utricle. In $A$, data were collected from serial cryostat utricular sections prepared from five utricles for each of the various time points. In $B$, data were collected from serial sections prepared from 5 E13, 5 E15, 5 E19, 5 P0, 10 P3, and 10 P7 rat utricles. Data are expressed as mean \pm SEM. There is a statistically significant reduction in hair cell number from $\mathrm{P} 3$ to $\mathrm{P} 7(p<0.01)$.

important role in preventing supporting cells from continuously generating new hair cells after P3.

\section{Calcium-binding proteins as markers for studies of hair cell differentiation and regeneration}

Although previous studies have reported expression of calretinin and other calcium-binding proteins in ganglion neurons and hair cells within the inner ear structures (Sans et al., 1986; Dechesne et al., 1993; Pack and Slepecky, 1995), the use of antibodies against these proteins has not been greatly appreciated or routinely practiced in hair cell regeneration studies. Instead, most hair cell regeneration or survival studies have relied on classic histological examination of the inner ear epithelium using light and electron microscopy (Weisleder and Rubel, 1992; Forge et al., 1993; Warchol et al., 1993) or the use of phalloidin staining of stereociliary bundles in organotypic cultures (Zheng and Gao, 1996). Our findings make the connection between the appearance of some calcium-binding proteins and the time course of hair cell differentiation and suggest that using calcium-binding protein antibodies to identify hair cells could greatly facilitate hair cell differentiation and regeneration studies. In particular, calretinin could be used as an early marker for hair cell regeneration in the vestibular end organs if regeneration of hair cells replicates the process of hair cell differentiation during development. Although calcium-binding proteins are not exclusive markers for hair cells because they label neurons in spiral and vestibular ganglia and other types of neurons in the brain (Beck et al., 1995), they can be used as selective markers to distinguish hair cells from supporting cells in the inner ear epithelium, especially during initial stages of hair cell differentiation or regeneration, or to identify surviving unlethally damaged hair cells. It has been noted that calretinin expression is downregulated in hair cells of the adult utricle and labels inner but not outer hair cells in the adult cochlea (Dechesne et al., 1994). In this regard, calmodulin may be used as a substitution because this molecule is present in adult inner ear hair cells (our unpublished observations) (see also Pack and Slepecky, 1995).

Intracellular calcium-binding proteins have been proposed to serve as mobile calcium carriers to buffer the fluctuation of cytosolic calcium concentration (Heizmann and Hunziker, 1991; Baimbridge et al., 1992). They are now widely used as specific markers for certain groups of neurons in the brain (Beck et al., 1995). It is interesting to note that in the nervous system the expression of these calcium-binding proteins is frequently coincident with neuronal differentiation and/or synaptogenesis (Baimbridge et al., 1992). Although the exact function of these proteins is still unclear, high levels of calcium-binding proteins in neurons and hair cells may be critical for cytoskeletal reorganization during cell differentiation, as shown in the regulation of growth cone activity (Kater and Mills, 1991).

\section{Apoptotic cell death of hair cells in the rat vestibular system}

Although apoptosis of hair cells was previously proposed by Kelley et al. (1993), the present study provides for the first time clear evidence that differentiated hair cells undergo apoptosis in vestibular end organs during normal development. This finding adds another cell type to the list of particular cell populations, including neurons and hematopoetic cells, which undergo apoptosis during normal development.

It is now a well known phenomenon that various types of neurons, regardless of whether they are derived from neural tube, neural crest, or placode tissues, undergo apoptosis during differentiation. Neuronal survival is dependent on neurotrophic factors available in their synaptic targets (Korsching, 1993; Gao et al., 1995a,b). It is believed that naturally occurring neuronal cell death is a necessary process to match neuronal numbers and their target populations (Oppenheim, 1991). The apoptosis of hair cells reported here $(\sim 12 \%)$ is not as robust as that occurring in the nervous system. Whether elimination of the overproduced hair cells enhances the fine tuning of hearing and balance sensitivity remains to be determined.

It is not clear how the apoptotic event is regulated during maturation of placode-derived hair cells, but it can be assumed that specific growth factors or expression of specific genes is involved. If the mechanism for apoptosis of hair cells during normal development is understood, it may be possible to prevent or ameliorate hair cell death induced by acoustic trauma or ototoxic insults. For example, neurotrophins that prevent neurons from apoptosis during development can also protect them from 

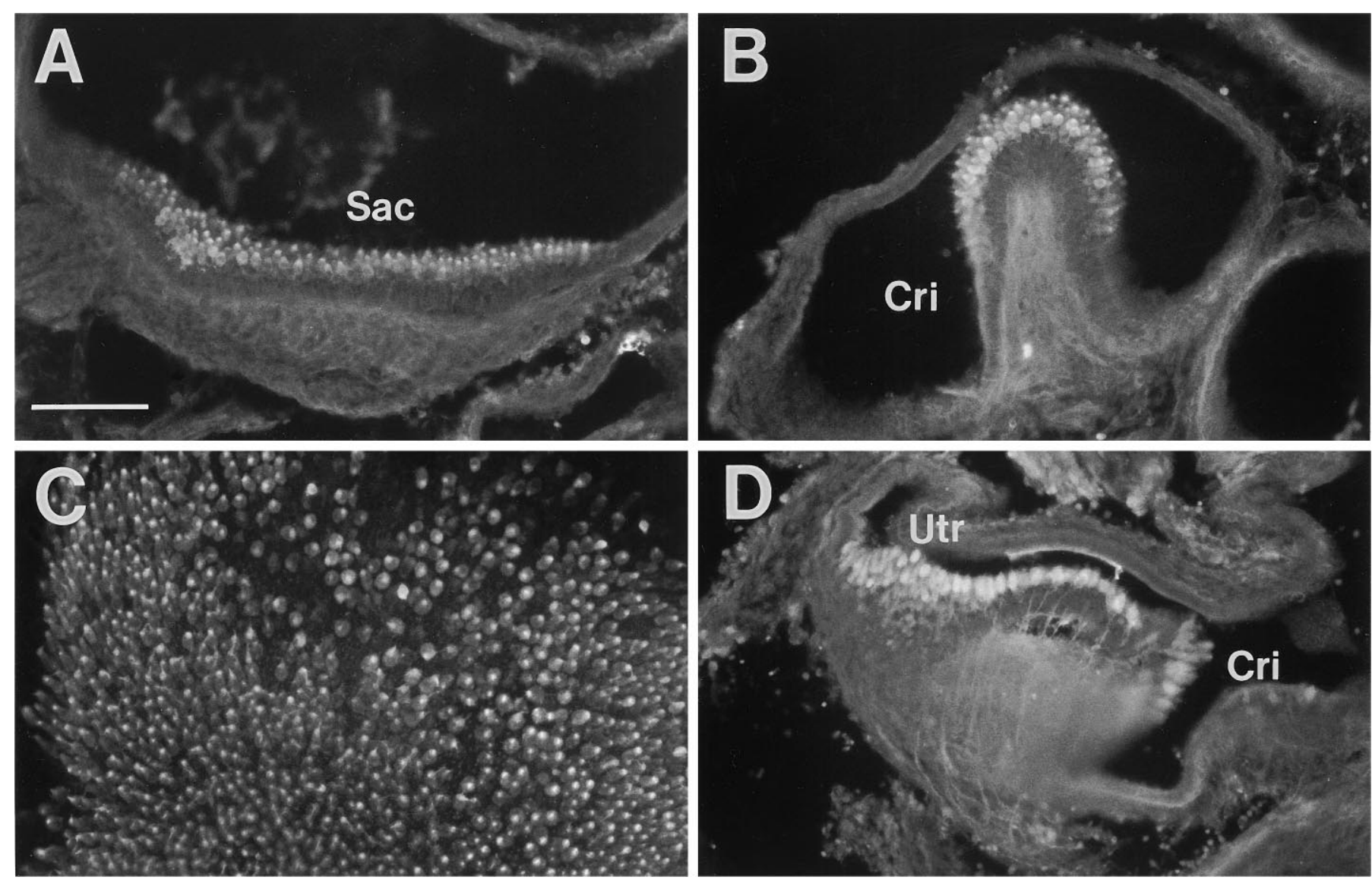

Figure 8. Immunolabeling of developing inner ear tissues with calmodulin and parvalbumin antibodies. $A, B$, Calmodulin immunostaining at E20. $C$, Calmodulin immunostaining of a cultured P4 utricular sheet at 2 DIV. D, Parvalbumin immunostaining at E20. Sac, Saccule; Cri, crista; Utr, utricle. Scale bar, $100 \mu \mathrm{m}$.

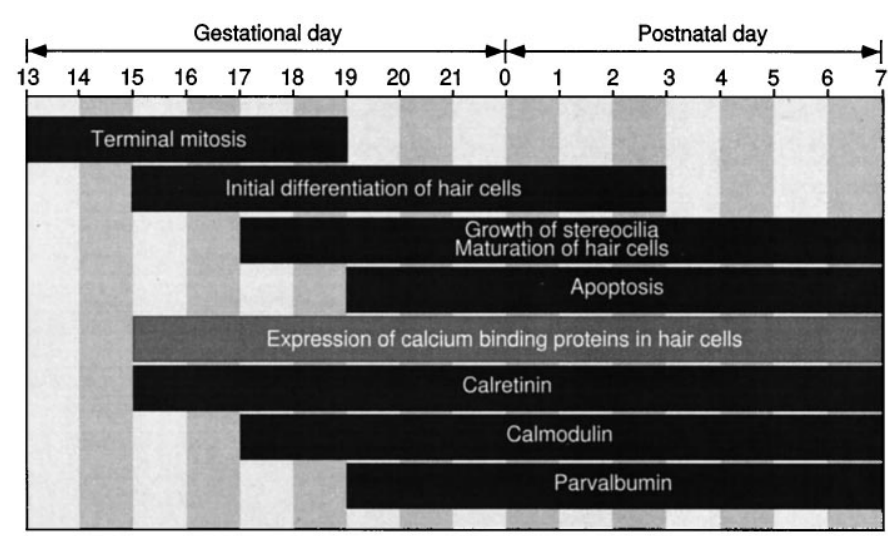

Figure 9. Developmental time course of rat vestibular hair cell differentiation and apoptosis. Note that there is a developmental gradient from the central to the peripheral region of the sensory epithelium.

neurotoxins (Gao et al., 1995b; Zheng et al., 1995a,b) or axotomy (Hefti, 1986). It is interesting to note that apoptosis also occurs during hair cell degeneration attributable to aminoglycoside treatment (Gray et al., 1996; Li et al., 1997) (our unpublished observations) and that IGF-1 can attenuate apoptosis induced by gentamicin in chick inner ear epithelium (Gray et al., 1996). In addition, the bcl-2 gene product has been indicated to regulate apoptosis in both immune (Hockenbery et al., 1990) and nervous (Garcia et al., 1992) systems. Overexpression of bcl-2 seems to induce abnormal inner ear development (Fekete et al., 1997). It will be interesting to identify the signal transduction pathway underlying hair cell apoptosis and determine whether specific growth factors could prevent this apoptosis in mammalian inner ears.

\section{Mechanisms of hair cell regeneration in mammalian inner ears}

In avian systems, proliferation of supporting cells has been shown to be a major event during hair cell regeneration (Corwin and Cotanche, 1988; Girod et al., 1989; Raphael, 1992; Weisleder and Rubel, 1992; Hashino and Salvi, 1993; Stone and Cotanche; 1994; Stone et al., 1996; Warchol and Corwin, 1996). However, whether injury-induced proliferation of supporting cells can lead directly to generation of new hair cells in mammals is still under debate (Forge et al., 1993, 1995; Warchol et al., 1993; Rubel et al., 1995; Warchol et al., 1995). Although utricular supporting cells finish proliferation before birth in normal animals (Ruben, 1967; Sans and Chat, 1982), they can be induced to proliferate in the partially dissociated cultures by enzymatic digestion and mechanical dissociation (Zheng et al., 1997) or in the undissociated utricular epithelial sheet cultures by exposure to high doses of gentamicin. When these cultures are maintained for an additional 7-11 d after gentamicin treatment in the presence of a mitotic tracer, a few mitotic supporting cells can differentiate into calretinin-positive cells. This finding provides direct supporting evidence for the 
model of proliferation-mediated hair cell regeneration. However, the number of calretinin and BrdU double-labeled cells is very low, suggesting that proliferation of supporting cells might not be the major mechanism for spontaneous hair cell regeneration in mammalian inner ears. It should be noted that these observations were made in the in vitro model, and some caution should be taken in generalizing to the in vivo situation.

Our finding of singlet calretinin and BrdU double-labeled cells in long-term cultures suggests a possibility of asymmetrical division. In this model, one progenitor cell gives rise to two daughter cells: one becomes a hair cell, the other remains as a supporting cell. Indeed, in some cases, a supporting cell (BrdU-positive but calretinin-negative cell) could be seen adjacent to the doublelabeled cell (Fig. 5B). Consistent with this notion, singlet or odd numbers of new hair cells have been seen in mammalian utricular epithelium in vitro or in vivo after aminoglycoside treatment (Warchol et al., 1993; Yamane, 1995) or in axolotl lateral lines after a laser ablation (Jones and Corwin, 1996). Whether asymmetrical division of hair cell progenitors occurs during normal development remains to be determined. Alternatively, one of the daughter cells dies after terminal mitosis. The observation that single calretinin and BrdU double-labeled cells are frequently seen sitting far away from other BrdU-labeled cells in the cultures suggests this possibility. Although we cannot rule out other possibilities, including DNA repairing of damaged hair cells and DNA replication by the hair cell itself, these possibilities are made less likely by our failure to detect any double-labeled cells with calretinin and BrdU double labeling of the cultures in the presence of BrdU for a short time ( $2 \mathrm{hr}$ to $5 \mathrm{~d}$ ) either after gentamicin treatment or in the intact undissociated utricular epithelial sheet cultures (Table 1). In addition, no double-labeled cells are seen when the cultures are treated with a mitotic blocker, aphidicolin ( $5 \mu \mathrm{g} / \mathrm{ml}$; data not shown). Moreover, it is generally believed that hair cells, like neurons, are postmitotic differentiated cells.

During preparation of this manuscript, Stone et al. (1996) reported that $\mathrm{TuJ} 1 \beta$-tubulin and calmodulin can be used as early hair cell markers during hair cell regeneration in chick cochlea. Using double immunocytochemical labeling with a DNA synthesis tracer and TuJ1 or calmodulin antibody, Stone et al. (1996) showed that supporting cells are triggered by ototoxic damage to undergo proliferation and many mitotic supporting cells differentiate into new hair cells in the chick cochlear epithelium. The newly differentiated hair cells do not form stereociliary bundles in the cultures. Although there are similarities between our study in rats and the work by Stone et al. (1996) in chicks, several differences are noticed. First, our study shows clearly that the appearance of calretinin coincides well with the initial stage of hair cell differentiation during normal development, which is earlier than stereociliary bundle formation as revealed by comparison of calretinin and phalloidin staining. Second, TuJ1 $\beta$-tubulin antibody labels inner ear ganglion neurons but does not label hair cells in rat inner ears (data not shown). Third, both proliferation of supporting cells and proliferation-mediated regeneration of new hair cells are much weaker in the mammalian utricular epithelium than those in the chick cochlear epithelium. Fourth, the generation of new hair cells seems to take longer in rats (7-11d) than in the chick (1-4 d). Finally, in chicks, higher numbers of BrdUpositive cells are seen immediately (2-3 d) after aminoglycoside treatment. However, in rats, more BrdU-positive cells are observed 5-11 d after ototoxic damage. The gradual increase of BrdU-positive cells in the rat utricular sensory epithelium after gentamicin treatment (Table 1) may also be attributable to the fact that supporting cells may go through more than one cell division cycle after hair cell degeneration (Jones and Corwin, 1993; Stone and Cotanche, 1994) because BrdU is continuously present in the cultures.

In addition to proliferation-mediated generation of new hair cells, there could be other mechanisms involved in hair cell regeneration. These include direct conversion of a subpopulation of supporting cells into hair cells (Adler and Raphael, 1996; Baird et al., 1996) and repair of unlethally damaged hair cells (Sobkowicz, 1992). At present, it is difficult to distinguish between these two possibilities because neither involves cell proliferation. When the stereociliary bundles are sheared off, it is hard to tell morphologically whether it is a damaged hair cell or a supporting cell. It is quite possible that unlethally damaged hair cells may repair their stereociliary bundles in mammalian inner ear epithelium (Sobkowicz, 1992; Zheng and Gao, 1997). Our observation that a considerable number $(23 \%)$ of hair cells survive after a high concentration of gentamicin $(3 \mathrm{~mm})$ treatment in the utricular epithelial sheet cultures may eventually provide a morphological base for the model of self-repair of partially damaged hair cells. On the other hand, self-repair of unlethally damaged hair cells is probably limited. Because acoustic and ototoxic injury does kill a large number of hair cells, regeneration of new hair cells is needed for a better recovery. However, the spontaneous proliferation-mediated regeneration of new hair cells seen in the cultures is a very rare event. Therefore it is interesting to note that certain growth factors may have the potential to facilitate repair or regeneration of mammalian inner ear hair cells (Kopke et al., 1996).

In summary, our observations have identified critical time periods for hair cell differentiation, regeneration, and apoptosis in mammals. Our study suggests that although proliferation of supporting cells might lead directly to generation of presumptive new hair cells, such a process is very limited and seems not to be the major mechanism for spontaneous hair cell regeneration in mammalian inner ears. Immunocytochemical markers such as calciumbinding proteins will be useful in hair cell regeneration studies for analysis of the survival of damaged hair cells and the initial differentiation or regeneration of new hair cells. Future studies are needed to determine whether specific growth factors can influence or facilitate differentiation and regeneration of hair cells, in addition to the induction of supporting cell proliferation (Lambert, 1994; Yamashita and Oesterle, 1995; Gu et al., 1996; Oesterle et al., 1997; Zheng et al., 1997).

\section{REFERENCES}

Adler HJ, Raphael Y (1996) New hair cells arise from supporting cell conversion in the acoustically damaged chick inner ear. Neurosci Lett 205:17-20.

Baimbridge KG, Celio MR, Roger JH (1992) Calcium-binding proteins in the nervous system. Trends Neurosci 15:303-309.

Baird RA, Torres MA, Schuff NR (1993) Hair cell regeneration in the bullfrog vestibular otolith organs following aminoglycoside toxicity. Hear Res 65:164-174.

Baird RA, Steyger PS, Schuff NR (1996) Mitotic and nonmitotic hair cell regeneration in the bullfrog vestibular otolith organs. Ann NY Acad Sci 781:59-70.

Balak KJ, Corwin JT, Jones JE (1990) Regenerated hair cells can originate from supporting cell progeny: evidence from phototoxicity and laser ablation experiments in the lateral line system. J Neurosci 10:2505-2512.

Beck KD, Powell-Braxton L, Widmer HR, Valverde J, Hefti F (1995) Igf1 gene disruption results in reduced brain size, CNS hypomyelina- 
tion, and loss of hippocampal granule and striatal parvalbumincontaining neurons. Neuron 14:717-730.

Corwin JT (1981) Postembryonic production and aging in inner ear hair cells in sharks. J Comp Neurol 210:541-543.

Corwin JT (1983) Postembryonic growth of the macula neglecta auditory detector in the ray, Raja clavata: continual increases in hair cell number, neural convergence, and physiological sensitivity. J Comp Neurol 217:345-356.

Corwin JT (1985) Perpetual production of hair cells and maturational changes in hair cell ultrastructure accompany postembryonic growth in an amphibian ear. Proc Natl Acad Sci USA 82:3911-3915.

Corwin JT, Cotanche DA (1988) Regeneration of sensory hair cells after acoustic trauma. Science 240:1772-1774.

Corwin JT, Jones JE, Katayama A, Kelley MW, Warchol ME (1991) Hair cell regeneration: the identities of progenitor cells, potential triggers and instructive cues. In: Regeneration of vertebrate sensory receptor cells (Bock G, Whelan J, eds), pp 103-119. New York: Wiley.

Corwin JT, Finley JE, Saffer R, Gu R, Cunningham L, Xia B, Warchol M (1995) Isolation of pure living hair cell epithelia by use of thermolysin. Assoc Res Otolaryngol Abstr 18:87.

Cotanche DA (1987) Regeneration of hair cell stereocilliary bundles in the chick cochlea following severe acoustic trauma. Hear Res 30:181-196.

Cruz RM, Lambert PR, Rubel EW (1987) Light microscopic evidence of hair cell regeneration after gentamicin toxicity in chick cochlea. Arch Otolaryngol Head Neck Surg 113:1058-1062.

Dechesne CJ, Winsky L, Moniot B, Raymond J (1993) Localization of calretinin mRNA in rat and guinea pig inner ear by in situ hybridization using radioactive and non-radioactive probes. Hear Res 69:91-97.

Dechesne CJ, Rabejac D, Desmadryl G (1994) Development of calretinin immunoreactivity in the mouse inner ear. J Comp Neurol 346:517-529.

Duckert LG, Rubel EW (1990) Ultrastructural observations on regenerating hair cells in the chick basilar papilla. Hear Res 48:161-182.

Fekete DM, Homburger S, Waring MT, Riedl AE, Garcia LF (1997) Involvement of programmed cell death in morphogenesis of the vertebrate inner ear. Development 124:2451-2461.

Forge A, Li L, Nevill G (1995) Response to: mammalian vestibular hair cell regeneration. Science 267:706-707.

Forge A, Li L, Corwin JT, Nevill G (1993) Ultrastructural evidence for hair cell regeneration in the mammalian inner ear. Science 259:1616-1619.

Gao W-Q, Hatten ME (1994) Immortalizing oncogenes subvert the establishment of granule cell identity in developing cerebellum. Development 120:1059-1070.

Gao W-Q, Heintz N, Hatten ME (1991) Cerebellar granule cell neurogenesis is regulated by cell-cell interactions in vitro. Neuron 6:705-715.

Gao W-Q, Zheng JL, Karihaloo M (1995a) Neurotrophin-4/5 (NT-4/5) and brain-derived neurotrophic factor (BDNF) act at later stages of cerebellar granule cell differentiation. J Neurosci 15:2656-2667.

Gao W-Q, Dybdal N, Shinsky N, Murnane A, Schmelzer C, Siegel M, Keller G, Hefti F, Phillips HS, Winslow JW (1995b) Neurotrophin-3 reverses cisplatin-induced peripheral sensory neuropathy. Ann Neurol 38:30-37.

Garcia I, Martinou I, Tsulimoto Y, Martinou JC (1992) Prevention of programmed cell death of sympathetic neurons by the bcl-2 protooncogene. Science 258:302-304.

Girod DA, Duckert LG, Rubel EW (1989) Possible precursors of regenerated hair cells in the avian cochlea following acoustic trauma. Hear Res 42:175-194.

Gray EMG, Warchol ME, Corwin JT (1996) IGF-1 protects hair cells from aminoglycoside-induced apoptotic cell death. Assoc Res Otolaryngol Abstr 19:198.

Gu R, Marchionni M, Corwin JT (1996) Glial growth factor enhances supporting cell proliferation in rodent vestibular epithelia cultured in isolation. Soc Neurosci Abstr 22:520.

Gu R, Lambert PR, Corwin JT (1997) Hair cell bundles in the utricles of mature guinea pigs. Am $\mathrm{J}$ Otol, in press.

Hashino E, Salvi RJ (1993) Changing spatial patterns of DNA replication in the noise-damaged chick cochlea. J Cell Sci 105:23-31.

Hashino E, Tanaka Y, Salvi RJ, Sokabe M (1992) Hair cell regeneration in the adult budgerigar after kanamycin toxicity. Hear Res 59:46-58.

Hefti F (1986) Nerve growth factor (NGF) promotes survival of septal cholinergic neurons after fimbrial transections. J Neurosci 6:2155-2162.
Heizmann CW, Hunziker W (1991) Intracellular calcium-binding proteins: more sites than insights. Trends Neurosci 16:98-103.

Hockenbery D, Nunes G, Milliman C, Schreiber RD, Korsmeyer SJ (1990) Bcl-2 is an inner mitochondrial membrane protein that blocks programmed cell death. Nature 348:334-336.

Jones JE, Corwin JT (1993) Replacement of lateral line sensory organs during tail regeneration in salamanders: identification of progenitor cells and analysis of leukocyte activity. J Neurosci 13:1022-1034.

Jones JE, Corwin JT (1996) Regeneration of sensory cells after laser ablation in the lateral line system: hair cell lineage and microphage behavior revealed by time-lapse video microscopy. J Neurosci 16:649-662.

Kater SB, Mills LR (1991) Regulation of growth cone behavior by calcium. J Neurosci 11:891-899.

Kelley MW, Xu XM, Wagner MA, Warchol ME, Corwin JT (1993) The developing organ of Corti contains retinoic acid and forms supernumerary hair cells in response to exogenous retinoic acid in culture. Development 119:1041-1053.

Kopke R, Garcia P, Feghali J, Gabaizadeh R, Liu W, Staecker H, Lefebvre PP, Van De Water TR (1996) In vivo treatment with TGFa/ IGF-1/retinoic acid mixture increase hair cell regeneration/repair in guinea pig utricles. Assoc Res Otolaryngol Abstr 19:198.

Korsching S (1993) The neurotrophic factor concept: a reexamination. J Neurosci 13:2739-2748.

Lambert PR (1994) Inner ear hair cell regeneration in a mammal: identification of a triggering factor. Laryngoscope 104:701-717.

Lendahl U, Zimmerman LB, McKay DG (1990) CNS stem cells express a new class of intermediate filament protein. Cell 60:585-595.

Lewis J (1991) Rules for the production of sensory cells. In: Regeneration of vertebrate sensory receptor cells (Bock G, Whelan J, eds), pp 25-39. New York: Wiley.

Li L, Forge A, Nevill G (1997) Apoptotic death of hair cells. Assoc Res Otolaryngol Abstr 20:112.

Oesterle EC, Tsue TT, Rubel EW (1997) Induction of cell proliferation in avian inner ear sensory epithelia by insulin-like growth factor-I and insulin. J Comp Neurol 380:262-274.

Oppenheim RW (1991) Cell death during development of the nervous system. Annu Rev Neurosci 14:453-501.

Pack AK, Slepecky NB (1995) Cytoskeletal and calcium-binding proteins in the mammalian organ of Corti: cell type-specific proteins displaying longitudinal and radial gradients. Hear Res 91:119-135.

Raphael Y (1992) Evidence for supporting cell mitosis in response to acoustic trauma in the avian inner ear. J Neurocytol 21:663-671.

Rubel EW, Dew LA, Roberson DW (1995) Mammalian vestibular hair cell regeneration. Science 267:701-703.

Ruben RJ (1967) Development of the inner ear of the mouse: a radioautographic study of terminal mitosis. Acta Otolaryngol [Suppl] 220:1-44.

Ryals BM, Rubel EW (1988) Hair cell regeneration after acoustic trauma in adult Coturnix quail. Science 240:1774-1776.

Sans A, Chat M (1982) Analysis of the temporal and spatial patterns of rat vestibular hair cell differentiation by tritiated thymidine radioautography. J Comp Neurol 206:1-8

Sans A, Etchecopar B, Brehier A, Thomasset M (1986) Immunocytochemical detection of vitamin D-dependent calcium-binding protein (CaBP-28K) in vestibular sensory hair cells and vestibular ganglion neurons of the cat. Brain Res 364:190-194.

Sobkowicz H, August BK, Slapnick SM (1992) Epithelial repair following mechanical injury of the developing organ of Corti in culture: an electron microscopic and autoradiographic study. Exp Neurol 115:44-49.

Stone JS, Cotanche DA (1994) Identification of the timing of S phase and the patterns of cell proliferation during hair cell regeneration in the chick cochlea. J Comp Neurol 341:50-67.

Stone JS, Leano SG, Baker LP, Rubel ER (1996) Hair cell differentiation in chick cochlear epithelium after aminoglycoside toxicity: in vivo and in vitro observations. J Neurosci 16:6157-6174.

Van De Water TR (1976) Effects of removal of the statoacoustic ganglion complex upon the growing otocyst. Ann Otol Rhinol Laryngol [Suppl 33] 85:1-32.

Warchol ME, Lambert PR, Goldstein BJ, Forge A, Corwin JT (1993) Regenerative proliferation in inner ear sensory epithelia from adult guinea pigs and humans. Science 259:1619-1622. 
Warchol ME, Lambert PR, Goldstein BJ, Forge A, Corwin JT (1995) Response to: mammalian vestibular hair cell regeneration. Science 267:704-706.

Warchol ME, Corwin JT (1996) Regenerative proliferation in organ cultures of the avian cochlea: identification of the initial progenitors and determination of the latency of the proliferative response. J Neurosci 16:5466-5477.

Weisleder P, Rubel EW (1992) Hair cell regeneration in the avian vestibular epithelium. Exp Neurol 115:2-6.

Yamane H, Nakagawa T, Iguchi H, Shibata S, Takayama M, Nishimura K, Nakai Y (1995) In vivo regeneration of vestibular hair cells of guinea pig. Acta Otolaryngol (Stockh) [Suppl] 520:174-177.

Yamashita H, Oesterle EC (1995) Induction of cell proliferation in mammalian inner ear sensory epithelia by transforming growth factor $\alpha$ and epidermal growth factor. Proc Natl Acad Sci USA 92:3152-3155.

Zheng JL, Gao W-Q (1996) Differential damage to auditory neurons and hair cells by ototoxins and neuroprotection by specific neurotrophins in rat cochlear organotypic cultures. Eur J Neurosci 8:1897-1905.

Zheng JL, Gao W-Q (1997) Self-repair is likely a major mechanism for spontaneous hair cell regeneration in rat utricles in vitro. Soc Neurosci Abstr 23:1822.

Zheng JL, Stewart RR, Gao W-Q (1995a) Neurotrophin-4/5 enhances survival of cultured spiral ganglion neurons and protects them from cisplatin neurotoxicity. J Neurosci 15:5079-5087.

Zheng JL, Stewart RR, Gao W-Q (1995b) Neurotrophin-4/5, brainderived neurotrophic factor, and neurotrophin-3 promote survival of cultured vestibular ganglion neurons and protect them against neurotoxicity of ototoxins. J Neurobiol 28:330-340.

Zheng, JL, Helbig C, Gao W-Q (1997) Induction of cell proliferation by fibroblast and insulin-like growth factors in pure rat inner ear epithelium cell cultures. J Neurosci 17:216-226. 